DOI https://doi.org/10.30525/978-9934-26-172-5-26

\title{
ІНФОРМАЦІЙНО-ЦИФРОВІ ТЕХНОЛОГІЇ ПРИ ВИРІШЕННІ ЗАВДАНЬ ГЕОФІЗИЧНОГО ЗАБЕЗПЕЧЕННЯ ПОЛЬОТІВ СФЕРИ ЦИВІЛЬНОЇ АВІАЦІЇ УКРАЇНИ
}

\author{
Калашник Г. А. \\ доктор геологічних наук, старший науковий співробітник, \\ професор кафедри аеронавігачіï \\ Льотна академія \\ Національного авіачійного університету \\ м. Кропивницький, Украӥна
}

Авіаційний транспорт залишається галуззю, що виробляє колосальний обсяг даних, лише мала частина якого реально використовується. Це величезний потенціал для розвитку i його реалізація на даний час здійснюється найактивнішим чином у різних напрямках, зокрема і в напрямку геофізичного забезпечення польотів сфери цивільної авіації. Багато трендів цифрової трансформації в різних складових авіаційної галузі сфокусовані i на взаємодії 3 клієнтом. Такий підхід закладено в основний галузевий документ Національну транспортну стратегію Україні до 2030 року, затверджену КМУ 30 травня 2018 р. № 430-p [1, c. 1]. У стратегії планується і передбачити поетапну цифровізацію транспортного комплексу, в тому числі для [1, с. 1-3]:

- створення основи безпілотного управління транспортом,

- переведення перевізних документів в електронний вигляд,

- переходу до моделювання транспортних потоків в режимі реального часу,

- використання технологій Big Data i штучного інтелекту (ШІ), зокрема при розширенні транспортної інфраструктури,

- застосування технології прогнозної (предиктивної) аналітики відмовних станів.

Всі ці напрямки стосуються і авіаційної галузі. Наприклад, технології штучного інтелекту вже активно застосовуються як на борту (в комплексі авіоніки літака), так і в завданнях при створенні техніки [2, c. 7].

У листопаді 2019 року була введена в дію нова служба цілодобового безперервного надання комерційній авіації i авіації загального призначення оновленої інформації про глобальну космічну погоду в режимі реального часу. Нова служба генерує і надає міжнародній авіації 106 
консультативні повідомлення про космічну погоду, використовуючи існуючу авіаційну фіксовану службу і дані, отримані від цільових глобальних центрів космічної погоди, створених в 14 країнах: консорціум за участю Австралії, Канади, Франції та Японії (ACFJ); консорціум PECASUS за участю Австрії, Бельгії, Кіпру, Фінляндії, Німеччини, Італії, Нідерландів, Польщі та Сполученого Королівства; центр, керований Сполученими Штатами Америки. Згідно планів ICAO не пізніше листопада 2022 року також ще будуть створені два нових регіональних центри виявлення явищ космічної погоди.

Всі глобальні і регіональні центри будуть приділяти основну увагу проявам сонячної активності, які можуть потенційно впливати на пов'язаний 3 повітряним транспортом високочастотний зв'язок, навігацію та спостереження, засновані на GNSS, і рівні радіації на борту цивільних повітряних суден. Ця нова можливість дозволить льотному екіпажу і фахівцям центрів польотної інформації користуватись найсвіжішою інформацією про будь-яких проявах сонячної активності, які можуть потенційно вплинути на роботу авіаційних систем або здоров'я пасажирів та льотного персоналу [3, с. 95].

Нова інформаційна служба космічної погоди на підтримку міжнародної аеронавігації надає консультативні повідомлення про космічну погоду безпосередньо експлуатантам повітряних суден та членам льотного екіпажу в рамках комплекту стандартної метеорологічної інформації, що відноситься до повного обсягу їх планових маршрутів, а також їх поновлення в ході польоту.

Консультативні повідомлення про космічну погоду також передаються районним диспетчерським центрам мережі повітряного транспорту, центрам польотної інформації, аеродромних метеорологічним органам, міжнародним банкам даних ОРMET (оперативна метеорологічна інформація), міжнародним офісам NOTAM та службам, заснованим на використанні Інтернету, в рамках авіаційної фіксованої служби.

Нова служба космічної погоди також буде залежати від координації діяльності та допомоги з боку національних центрів OPMET (NOC), регіональних центрів OPMET (ROC), регіональних банків даних OPMET (RODB) і міжрегіональних шлюзів OPMET (IROG), які будуть відповідати за отримання і поширення консультативних повідомлень про космічну погоду.

Для надання допомоги державам i користувачам при вирішенні проблеми певних факторів ризику для безпеки польотів 3 боку геліогеофізичних явищ та процесів ICAO випустила нове Керівництво по використанню інформації про космічну погоди на підтримку 
міжнародної аеронавігації (Doc. 10100 ICAO [4]) та оновлене Керівництво з авіаційної метеорології (Doc. 8896 ICAO [5]).

Нажаль, до теперішнього часу в Україні відсутні сучасні вітчизняні джерела інформації з космічної погоди, здатні демонструвати оцінки поточної геліогеофізичної обстановки. Подальша відсутність в Україні служби геофізичного забезпечення для підвищення ефективності роботи радіотехнічних засобів різного призначення, включаючи обслуговування сфери авіації, не відповідає вимогам національної безпеки України, позбавляє можливості оперативного реагування на природні та техногенні процеси негативного характеру, не дозволяє в повній мірі забезпечувати безпеку польотів в сфері цивільної авіації, згідно з вимогами ICAO.

Отже, сучасна авіаційна галузь України в умовах цифровізації у провідних галузях технологій має потребу до підготовки здобувачів вищої освіти спеціальності 272 «Авіаційний транспорт», здатних до використання інноваційних інформаційно-цифрових технологій, зокрема у напрямку геофізичного забезпечення польотів, а також до нестандартних дій у разі необхідності мінімізації негативного впливу небезпечних геліогеофізичних явищ, до творчого розв'язання нагальних проблем дижитилізації у сфері цивільної авіації.

У сфері професійної підготовки авіаційних фахівців в Льотній академії Національного авіаційного університету курс навчальної дисципліни “Основи геофізичного забезпечення польотів" інтегрує спеціальні знання, практичні навички й уміння щодо використання методів, засобів і сучасних технологій для вирішення професійних завдань оперативного отримання, збору, обробки, аналізу та прогнозування стану динаміки геофізичних полів в різних геосферах Землі, які можуть негативно впливати на безпеку польотів повітряних суден, можливі наслідки таких впливів і методи їх запобігання або мінімізації, застосування механізмів регулювання дозових навантажень льотного персоналу, отриманих внаслідок впливу галактичних та сонячних космічних променів, методів радіаційного контролю членів льотних екіпажів повітряних суден на висотах авіаперельотів, та практичне використання їх результатів для потреб цивільної авіації відповідно до вимог низки документів ICAО [4]; [5].

Навички використання інформаційних і комунікаційних технологій у майбутніх авіаційних фахівців є нагальною необхідністю для ефективного отримання, аналізу, інтерпретації комплексних звітів та прогнозів стану космічної погоди на передпольотному етапі та у процесі виконання польоту повітряних суден (ПС) цивільної авіації (ЦА) за заданим маршрутом; для адекватної оцінки ситуації відповідно до критеріїв небезпечних 
геліогеофізичних явищ за класифікацією NOAA Space Weather [6, с. 1-3]; для оцінки можливих наслідків впливу небезпечних геліогеофізичних явищ та впровадження адекватних заходів 3 мінімізації їх негативних впливів на технічні системи та біологічні об'єкти у подальшій професійній діяльності авіаційного фахівця.

Таким чином, цифрова трансформація вимагає у майбутніх авіаційних фахівців сформованості стійких компетенцій в області машинного навчання, роботи з даними, комп'ютерного зору, математичного моделювання, інтернету речей i сучасних підходів до розробки програмного забезпечення та управління процесами. В основі освітнього процесу в Льотній академії НАУ лежить принцип випереджаючого навчання - забезпечення для курсантів можливості безпосередньо знайомитися 3 новітніми авіаційними технологіями для оволодіння актуальними знаннями, вміннями і навичками для подальшій ефективній роботи у цивільній авіації відповідно до вимог стандартів, правил i рекомендацій Міжнародної організації цивільної авіації (ICAO), Свропейського агентства з безпеки польотів (EASA).

\section{Література:}

1. Національна транспортна стратегія Україні до 2030 року, затверджена КМУ 30 травня 2018 р. № 430-p. Редакція від 07.04.2021 URL: https://zakon.rada.gov.ua/laws/show/430-2018 (дата звернення: 02.12.2021).

2. Калашник Г.А., Калашник-Рибалко М.А. Ознаки та критерії функціональної стійкості інтегрованого комплексу бортового обладнання сучасного повітряного судна та перспективні напрямки його розвитку. Збірник наукових працьь Харківського національного університету Повітряних сил. 2021. № 2(42). С. 7-15. DOI: https://doi.org/10.30748/zhups.2021.68.01

3. Калашник Г.А., Калашник-Рибалко М.А. Основні заходи щодо забезпечення ефективного функціонування систем управління, зв'язку та навігації в умовах впливу деструктивних геліогеофізичних збурень. Наука і техніка Повітряних Сил Збройних сил Украӥни. 2018. № 1. C. 92-98. DOI: https://doi.org/10.30748/nitps.2018.30.13

4. ICAO, 2021. Doc. 8896 "Manual of Aeronautical Meteorological Practice", 13th Edition 2021. 16 p.

5. ICAO, 2019. Doc. 10100 "Manual on Space Weather Information in Support of International Air Navigation", November 2019. 48 p.

6. NOAA Space Weather Scales [Електронний ресурс]: [Сайт]. URL: https://www.swpc.noaa.gov/noaa-scales-explanation (дата звернення: 02.12.2021). 